\title{
Failure is an Option: Impediments to Short Selling and Options Prices
}

\author{
Richard B. Evans \\ Christopher C. Geczy \\ David K. Musto \\ Adam V. Reed*
}

This Version: December 7, 2005

\begin{abstract}
Regulations allow market makers to short sell without borrowing stock, and the transactions of a major options market maker show that in most hard-to-borrow situations, it chooses not to borrow and instead fails to deliver stock to its buyers. Some of the value of failing passes through to option prices: when failing is cheaper than borrowing, the relation between borrowing costs and option prices is significantly weaker. The remaining value is profit to the market maker, and its ability to profit despite the usual competition between market makers appears to result from a cost advantage of larger market makers at failing.
\end{abstract}

\footnotetext{
* Evans is from the Carroll School of Management at Boston College. Geczy and Musto are from The Wharton School at the University of Pennsylvania. Reed is from the Kenan-Flagler Business School at the University of North Carolina. We gratefully acknowledge important input from an anonymous referee, Michael Brandt, Greg Brown, Jennifer Conrad, George Constantinides, Patrick Dennis, Darrell Duffie, Bin Gao, Eitan Goldman, Jonathan Karpoff, Richard Rendleman and seminar participants at Notre Dame, USC, UT, Wharton and the Western Finance Association Meetings. We thank Wes Gray for excellent research assistance. The Frank Russell Company generously provided constitution lists for their Russell 3000 index. Corresponding Author: Adam Reed; Campus Box 3490, McColl Building; Chapel Hill, NC 27514. Phone: (919) 962-9785. E-mail: adam_reed@unc.edu.
} 
The market for short exposure in the United States clears differently from the market for long exposure. This difference has attracted considerable recent interest from both the SEC and market participants who frequently short-sell or whose stock is sold short. ${ }^{1}$ The interest is in both the economics of clearing and in the pricing of the affected assets, which could be high or inefficient. Our goal is to establish the role and economic significance of an unfamiliar but important clearing tactic: failing to deliver.

Short sales are usually accomplished through equity loans. The short-seller borrows shares from an equity lender which he delivers to the buyer. This debt of shares to the lender gives him short exposure going forward. But there is another way to create the same exposure: by failing to deliver the shares. If the short-seller delivers nothing to the buyer, thereby incurring a debt of shares to the buyer, this also gives him short exposure going forward. This alternative moves the risk that the short-seller does not repay his debt from the equity lender to the buyer, but just as equity lenders have a mechanism for ensuring performance, i.e. collateral, so does the buyer. The clearing corporation intermediating the trade takes margin and marks it to market, thereby defending buyers against their sellers' non-performance. If equity loans are expensive, unavailable, or unreliable, as research shows they can be (e.g. D'Avolio, 2002, Geczy, Musto and Reed, 2002, Jones and Lamont, 2002, Lamont 2004) then this alternative appears desirable, to short sellers if not to buyers. But considering the market rules that bind short sales to equity loans, how is it feasible?

\footnotetext{
${ }^{1}$ In July of 2004 the SEC passed regulation SHO which limits the ability of certain market participants to sell stock short without borrowing to cover their position. The discussion period for regulation SHO attracted considerable attention from the business press.
} 
The answer, we show, lies in the special access to delivery fails that option market-makers enjoy. Traders are generally obliged to locate shares to borrow before shorting, but those engaged in bona-fide hedging of market-making activity are exempt from this requirement. So unlike traders in general, a market maker can short sell without having located shares to borrow. If he does not locate shares to borrow then he fails to deliver, someone on the other side fails to receive, and therefore retains the purchase price, and the clearing corporation starts taking margin. While it lasts, this arrangement is effectively an equity loan from the buyer to the seller at a zero rebate. But whether it lasts depends on the reaction of the trader being failed to. If a buyer does not get his shares then he can demand them, in which case a short-seller who failed is bought in: he must go buy the shares and hand them over. If that short-seller wants to maintain his short exposure he must short again, so this demand increases his shorting cost by this roundtrip transactions cost. Thus, the cost of failing to deliver is the cost of a zero-rebate equity loan plus the expected incidence of buy-in costs. If this incidence is low enough, then failing is a valuable alternative to borrowing the harder-to-borrow stocks. We show that the alternative to fail is valuable and key to the pricing and trading of options.

First, we show that shorting costs move options out of parity. That is, synthetic shorts constructed from options trade below spot-market prices when shorting is costly, i.e. when interest rebates on equity loans are low, and this disparity grows as the rebate falls. However, this growth slows when the rebate falls below zero, consistent with option market-makers choosing failure over negative rebates, and sharing some of the savings. Furthermore, the short interest of a major option market maker grows, as a 
fraction of marketwide short interest, as rebates fall, consistent with the market maker having and sharing an advantage getting short exposure to hard-to-borrow stocks.

We can see the advantage directly in the market maker's shorting experience. Half the time the market maker shorts a hard-to-borrow stock, it fails to deliver at least some of the shares. And it never accepts a negative rebate, always choosing to fail instead. This advantage could in principle be offset by frequent buy-ins, but we find a very low frequency of buy-ins, executed with small price concessions.

How much of this advantage does the market maker share? Estimating the market maker's trading profits, net of rebate reductions and buy-ins, we document a significant average profit. This profit seems at odds with the competitiveness of options markets, but we show that it corresponds to the way the clearing corporation handles buy-ins. The highest-volume option market makers, such as our data supplier, likely benefit from the clearing corporation's practice of assigning buy-ins to the oldest fails. That is, when a number of short-sellers' brokers are failing on the same stock and a buyer's broker demands shares, the clearing corporation passes this demand to the broker whose fail started first. This favors the few highest-volume traders because, since their portfolios turn over so much, their fails are rarely the oldest. Thus, we hypothesize that optionmarket competition tends to oligopoly as stocks grow hard to short.

To test our hypothesis that market-maker competition weakens as specialness grows, we test whether options' bid/ask spreads grow as specialness grows. We find that they do. We also find that our data provider, a large market maker, is bought in much less frequently than average, and that when it is bought it in, this corresponds to when 
option volume is lower, and therefore its advantage at avoiding buy-ins is smaller. We therefore conclude that at least some of the profits result from limits to competition.

The rest of this paper is organized as follows. Section I reviews the literature, Section II describes the database, Section III presents the results and Section IV concludes. An appendix provides background information and relevant details regarding short selling and delivery.

\section{Related Literature}

This paper is not the first to document that shorting frictions associate with breakdowns of put call parity. Lamont and Thaler (2001) find that impediments to short selling prevent traders from exploiting seemingly profitable arbitrage strategies resulting from the misalignment of stock prices in equity carve-outs. Similarly, Ofek, Richardson and Whitelaw (2004) measure the relationship between increased borrowing costs and put-call disparity and find cumulative abnormal returns for arbitrage strategies involving put-call disparity exceed 65\%. But, as in Jarrow and O’Hara (1989), market imperfections prevent most arbitrageurs from turning the misalignment into a profit. The put-call parity trades studied here can only be performed by market participants who can always borrow stock or short sell without borrowing stock. In other words, rebate rates are only valid if stocks are found and borrowed. Our study has the unique advantage of a coherent approach that combines actual borrowing costs and feasibility for one market participant: a large options market maker.

Furthermore, this paper is not the first to discuss settlement fails; there is a strand of literature which studies settlement and settlement failures in markets other than U.S. 
equities. In the context of monetary policy, Johnson (1998) finds that technological improvements in the banking settlement system have affected monetary policy. In the context of foreign exchange, Kahn and Roberds (2001), show that settlement through a private intermediary bank can mitigate some of the unique risks associated with foreign exchange settlement. Fleming and Garbade (2002) find that settlement fails jumped following the September $11^{\text {th }}$ attacks as a result of the destruction of communication facilities. $^{2}$

In this paper, we identify the possibility of profiting from the misalignment, due to short-sale costs, of stock and options markets for market participants who have the option to fail to deliver shares, and we show how limited access to this option is a barrier to entry that prevents competition from realigning market prices. This work relates primarily to three topics in the finance literature: equity lending, the relation of observed prices to Black-Scholes, and deviations from put-call parity. We briefly review each.

\section{A. The Equity Lending Market.}

A number of recent papers have examined variation in the cost of borrowing stock in the equity lending market. Reed (2002) uses one year of daily equity loan data to measure the reduction in informational efficiency resulting from short-sale costs. Geczy, Musto and Reed (2002) measure the impact of equity-loan prices on a variety of trading strategies involving short selling. The paper finds prices in the equity lending market do not preclude short-sellers from getting negative exposure to effects on average, but in the

\footnotetext{
${ }^{2}$ More recently, Boni (2005) explores market-wide failing data from the clearing corporation.
} 
case of stock-specific merger arbitrage trades, short selling impediments reduce profits substantially. Christoffersen, Geczy, Musto and Reed (2005a, 2005b) use the same database to study stock loans that are not necessarily related to short selling. The paper finds an increase in both quantity and price of loans on dividend record dates when the transfer of legal ownership leads to tax benefits. Using another database of rebate rates, Ofek and Richardson (2003) demonstrate that short selling is generally more difficult for Internet stocks in early 2000, and D'Avolio (2002) uses 18 months of daily data to relate specialness to a variety of stock-specific characteristics. Jones and Lamont (2002) study borrowing around the crash of 1929; the paper finds that hard-to-borrow stocks had low future returns. Finally, Duffie, Gârleanu and Pedersen (2002) formulate a search model of the equity lending market.

\section{B. Predicted and Observed Options Prices.}

By relating short selling to option prices, this paper also contributes to the large literature on the difference between Black-Scholes (1973) options prices and observed option prices. MacBeth and Merville (1979) and Rubinstein (1985) show that, empirically, implied volatilities are not equal across option classes and that deviations are systematic. As in Derman and Kani (1994), these systematic deviations are commonly referred to as the volatility smile. Longstaff (1995) shows that the difference between Black-Scholes and actual option prices increase with option bid-ask spreads and decrease with market liquidity. While Longstaff's results are contested in later work (i.e. Strong and $\mathrm{Xu}(1999))$, he provides a novel approach to testing the impact of market frictions on 
option prices. Dumas, Flemming and Whaley (1998) test a range of time- and statedependent models of volatility meant to account for observed deviations from BlackScholes prices. The paper concludes that these models still leave a large mean-square error when explaining market prices. Using Spanish index options, Peña, Rubio and Serna (1999) find evidence consistent with U.S. markets; they find a positive and significant contribution of the bid-ask spread to the slope of the volatility smile. Dennis and Mayhew (2000) examine the contribution of various measures of market risk and sentiment on individual index options and find that both are correlated with the smile.

\section{Tests of Put-Call Parity}

Some of the evidence on the impact of short-sale impediments on options prices is presented here in terms of put-call parity. Tests of put-call parity date back to Klemkosky and Resnick (1979) who find option market prices to be largely consistent with put-call parity. In a related paper that focuses on the speed of adjustment of option and stock markets, Manaster and Rendleman (1982) conclude that closing options prices contain information about equilibrium stock prices that is not contained in closing stock prices. While the implied stock price measure employed in our work differs substantially from that of Manaster and Rendleman (1982), the approach of comparing actual and implied stock prices is similar.

\section{Data}


We combine several databases in this study. First, a prominent options market maker provided rebate rates, failing positions and a database of buy-ins and execution prices on those buy-ins. For equity options prices, implied volatilities, option volume and open interest, we use the OptionMetrics database. Finally, the interest rate term structure is estimated using commercial paper rates from the Federal Reserve (see Appendix B for details).

\section{A. Rebate Rates, Fails and Buy-Ins.}

A large options market-making firm has generously provided a database of their rebate rates, fails and buy-ins for 1998 and 1999. The rebate rates are the interest rates on cash collateral for stock loans quoted by the market maker's prime broker. Different borrowers are likely to face different rates; this database is a description of one large market maker's experience. As discussed in Geczy, Musto and Reed (2002), rebate rates allow us to measure the difficulty of borrowing shares, or specialness.

We construct a measure of specialness for each stock on each date. Specifically, specialness on any stock is the difference between the general collateral rate and the rebate rate on that stock. Following Geczy, Musto and Reed (2002), we estimate the general collateral rate as the Federal Funds Rate minus the equity lender's fixed commission. Specialness is zero for most stocks, and it is positive for specials, or hardto-borrow stocks. In Panel B of Table IV, we augment our market maker's specialness database with specialness from a large custodian lender as described in Geczy, Musto and Reed (2002). 
The rebate rates cover all stocks in the Russell 3000 index, and we have limited our other databases to that subset of U.S. equities using constitution lists from the Frank Russell Company. The Russell 3000 includes the 3000 largest stocks in the U.S based on May 31st market capitalization. In 1997, stocks larger than $\$ 171.7 \mathrm{M}$ were included. The cutoff was \$221.9M in 1998 and \$171.2M in 1999 .

The database also indicates when this market maker is failing to deliver shares on any of its short positions. Even though we do not have data on any of this market maker's specific trades, we do have information about this market maker's buy-ins. The buy-in database has purchase dates, settlement dates and execution prices for every buyin 1998 and 1999.

\section{B. Options Data}

We use the Ivy DB OptionMetrics database for US Equity option prices, spreads and volume. We use the average of the lowest closing ask and the highest closing bid, or the midquote, as the options price. We apply three filters that are common elsewhere in the options literature (e.g. Dumas, Whaley and Fleming (1998) and Bakshi, Cao and Chen (1997)). First, we remove options with fewer than 6 calendar days to maturity to mitigate liquidity bias. Second, we remove options with prices less than $\$ 0.375$ to minimize price discreteness. Third, as described in Table I, no-arbitrage restrictions are applied to the option quotes.

Table I indicates that he intersection of the rebate and option databases contains 19,723,466 observations. After filtering, the database contains 11,437,401 observations. 
This is daily price data for options with various strike prices and maturity dates on 449,721 unique stock/days. On average, there are 890 stocks per day on the 504 trading days in the sample.

\section{Results}

The empirical results are ordered as follows. First, we address the significance to a market maker of its option to fail, both in the incidence of failing and in the relation of failing to high equity-loan costs. Next, we relate equity-loan costs to the price of a synthetic short position as determined by put-call parity, and we ask if this relation is sensitive to whether the option to fail is in the money, i.e. whether the rebate rate is less than zero. Then we gauge whether the mispricing of the synthetic short position is a result of expensive puts or cheap calls using implied volatility as a measure of price. We then calculate the expected cost of buy-ins, which is the product of the incidence of buyins and their execution quality. Using this actual incidence and price of buy-ins, we compute the market-maker's net profits from providing synthetic shorts in hard-toborrow situations. Finally, in response to the positive profits we document, we address the possibility that option-market competition is limited when the underlying is hard to borrow.

\section{A. Specialness and Delivery Failure}


Our database shows the data supplier's short position, for each stock in the Russell 3000 and each day in 1998-99, and in particular it shows whether the position was achieved through borrowing, failing or both. It also tells us the rebate received on borrowed shares, whether failed shares were bought in, and if so, at what price. Thus, we can sort short positions into five major categories: General Collateral, Reduced Rebate, Reduced Rebate and Fail, Fail Only and Buy-In. General Collateral indicates that a stock has been loaned at the normal rebate rate; i.e. the stock is easy to borrow. Reduced Rebate indicates that the rebate rate is below the general collateral rate; i.e. the stock is on special. Reduced Rebate and Fail indicates that some shares have been borrowed at a reduced rebate, and that the market maker failed to deliver some shares that were sold short. Fail Only indicates that the market maker failed to deliver any of the shares in this short position. Buy-In indicates that the counterparty of the short-sale transaction is forcing delivery on some or all of the shares in the short position. Table II, Panel A, reports the incidence of each.

Consistent with earlier work, a large majority, $91.24 \%$, of stocks are available for borrowing at general collateral rates. The remaining $8.76 \%$ are the specials. Breaking out this $8.76 \%$, we find $4.19 \%$ where borrowing simply continues at lower rebates, but in the remaining $4.57 \%$ the market maker fails to deliver, partially or completely. Failing is thus an important part of the story; more than half of the time the option to fail is used when stocks are on special. Any analysis of the relationship between short-sale impediments and options prices is at least incomplete, and perhaps severely biased, without consideration of the option to fail. 
We would expect options market makers to fail more often as rebate rates fall to zero. Our sample bears this out. Panel B of Table II shows $89.65 \%$ of the failing positions occurring when rebates are at the lowest rate in our sample, zero, and only $1.39 \%$ of the non-failing positions have rebates at zero. So failing predominates when rebates hit zero, and delivery predominates when rebates are positive. We also find, in unreported results, that the probability of at least some failure grows $15.66 \%$ for each $1 \%$ decrease in the rebate. ${ }^{3}$ Thus we conclude that failure is tightly linked to low rebates.

\section{B. Specialness and Option Prices.}

We expect option prices to reflect the costs of hedging, including the costs of short selling. We use our measure of short-sale costs, specialness, and two measures of options prices to characterize this relationship. First, we use put-call parity to measure misalignments of stock and options markets. Second, we refer to the options' implied volatilities, as calculated in Cox, Ross and Rubinstein (1979), to gauge whether puts or calls are more responsible for what we find.

\section{B.1. Put-Call Parity}

The effect of short-sale costs on option prices can be seen via the European putcall parity relation. Put-call parity states that the value of a European call option plus the discounted value of the option's strike price is equal to the value of the underlying asset plus the value of a European put with the same strike price and maturity:

\footnotetext{
${ }^{3}$ Taking those observations for which specialness is positive and the rebate rate is positive, we run a logistic regression of failing on specialness with cross-sectional and time-series fixed effects. The dependent variable is 1 if there is any failing in a particular stock on a given day. The coefficient estimate on specialness is 0.1455 ( $\mathrm{p}$-value $<0.0001$ ). The odds ratio point estimate is 1.1566 .
} 


$$
\mathrm{C}+\mathrm{e}^{-\mathrm{r} \tau} \mathrm{K}=\mathrm{P}+\mathrm{S}
$$

where $C$ is the price of a European call option on stock $S$ with strike price $K$, $e^{-r \tau} K$ is the present value of $\mathrm{K}$, and $\mathrm{P}$ is a put option with strike price $\mathrm{K}$. $\mathrm{C}$ and $\mathrm{P}$ are assumed to have the same time to maturity, $\tau$.

This relationship allows a trader to replicate the payoffs of any single instrument in the equation with a combination of the other three instruments. For example, the stock price implied by this put-call parity relationship, or the implied stock price, is

$$
\mathrm{S}^{\mathrm{i}}=\mathrm{C}-\mathrm{P}+\mathrm{e}^{-\mathrm{r} \tau} \mathrm{K}
$$

For stocks with dividends paid during the life of the option, the present value of dividends is added to the right hand side of the equation.

After computing the stock price implied by put-call parity, we compute the percentage deviation of the implied stock price from the actual stock price. This is computed by subtracting the implied stock price from the actual stock price and normalizing by the actual stock price:

$$
\Delta_{j, t}=\frac{S_{j, t}-S_{j, t}^{i}}{S_{j, t}}
$$

where $S_{j, t}$ is the price of stock j on day t from the spot market and $S_{j, t}^{i}$ is the price of stock $\mathrm{j}$ on day $\mathrm{t}$ implied by put-call parity. We refer to $\Delta_{j, t}$ as put-call disparity. Table III shows the distribution of this measure, which shows some dispersion; the $5^{\text {th }}$ percentile is $-0.98 \%$ and the $95^{\text {th }}$ percentile is $1.95 \%$.

Some of this dispersion does not relate to arbitrage opportunities. Dividendrelated early exercise differentiates the European options of the parity relation from the 
American options of the database; we address this below by excluding stocks that paid dividends in the past year. Early exercise also arises with deep-in-the-money puts, which we address by using only the option pair with moneyness $(\mathrm{S} / \mathrm{K})$ closest to one, and shortest time to expiration. Since near-the-money and close-to-maturity options tend to be more actively traded, this also mitigates the effects of stale prices, which we further address by removing options for which the volume or open interest is equal to zero.

Another source of dispersion is microstructure effects. As Battalio and Schultz (2005) document, end-of-day prices deliver noisy estimates of actual arbitrage opportunities, as they may not be prices that were simultaneously available for trade. And even if prices are simultaneous and midpoint prices are exactly in line with put-call parity, if the stock price were at either an ask or a bid while the options were both at their midpoints, put-call disparity for the average stock in our sample would be $0.53 \%{ }^{4}$. But as long as these measurement errors do not correlate with rebates, they do not interfere with our tests. That is, they are as likely to subtract from our measured profits as add to them.

We test the null hypothesis that short selling is not associated with put-call disparity with the following regression:

$$
\Delta_{j, t}=\mathrm{a}+\text { bSpecialness }_{\mathrm{j}, \mathrm{t}}+\mathrm{c} \text { Moneyness } s_{\mathrm{j}, \mathrm{t}}+\mathrm{d} \text { Time-to-Maturity } \text { Tit, }_{\mathrm{t}}+\mathrm{e}_{\mathrm{j}, \mathrm{t}}
$$

where Specialness $_{j, t}$ is specialness in stock $j$ on date $t$. Moneyness is defined as the stock price divided by the strike price and Time-to-Maturity is the number of calendar days to

\footnotetext{
${ }^{4}$ The median bid-ask spread in stocks in our sample is $\$ 0.23$ (mean $\$ 0.25$ ). The median stock price in the sample is $\$ 21.69$ (mean $\$ 27.04$ ). If put and call prices are midpoints and the stock is at either the bid or the ask, then put call parity will be different from zero by $0.23 /(2 * 21.69)=0.0053$.
} 
expiration of the option. We include fixed effects for both time series and cross-sectional effects. Panel A of Table IV reports the fitted model.

The significantly negative coefficient on Specialness confirms that as specialness increases, so does the shortfall of synthetic short from the spot. Thus, specialness passes through to option prices, consistent with findings elsewhere. The new question is whether the option to fail passes through to option prices. Since the option to fail can reduce a market maker's shorting costs when rebates are negative, but not when they are positive, its effect would be a weakening of the relation between specialness and option prices as rebates go negative. That is, reducing the rebate from $2 \%$ to $1 \%$ increases the market maker's shorting cost by exactly that much, as failing is not a cheaper alternative to borrowing in either case, but reducing it from $-1 \%$ to $-2 \%$ increases it less, to the extent that market maker is failing rather than borrowing. To test this hypothesis we need to use specialness data that shows when the market rebate is negative, so we use the 'custodial' data instead.

The test design is the same as before, only that now we focus on just the stocks that are currently on special, and we add a regressor Negative Rebate Specialness which is zero when the rebate is positive, and is equal to the specialness, i.e. has the same value as Specialness, when the rebate is negative. The null hypothesis is that the coefficient on Negative Rebate Specialness is not significantly negative. The result is in Table IV, Panel B.

The regression rejects the null; the relation between rebates and option prices is indeed significantly weaker - at the point estimate, about $50 \%$ less - for negative than for 
positive rebates. This indicates that the option to fail plays a significant role in option pricing.

\section{B.2. Distinguishing the Effect on Puts and Calls}

The relation between specialness and synthetic shorts indicates some combination of puts growing expensive and calls growing cheap. To gauge whether one is more important than the other, we need to separate puts from calls and relate their prices to model. The testable questions become, are the implied volatilities of the puts significantly high, and are the implied volatilities of the calls significantly low?

For each option, we use implied volatility from OptionMetrics, which uses the industry standard Cox, Ross and Rubinstein (1979) binomial tree method for calculating implied volatilities. Using a fixed effects regression, we examine the relationship of implied volatilities with the moneyness, time-to-maturity, and specialness as well as time-series and cross-sectional fixed effects. The estimation results from several parameterizations of the following regressions are presented in Table V.

$$
\sigma_{j, t}^{\text {implied }}=\gamma_{0}+\gamma_{1} \text { Moneyness }_{j, t}+\gamma_{2} \text { Time-to-Maturity }_{j, t}+\gamma_{3} \text { Specialness }_{j, t}+e_{j, t}
$$

where moneyness is defined as $\mathrm{S} / \mathrm{K}$, and time to maturity is measured in calendar days. We include fixed effects for both time series and cross-sectional effects. Consistent with the results for index options from Derman and Kani (1994) and Longstaff (1985), we find that the implied volatility of put options increases with moneyness. The coefficient on 
moneyness for call options is statistically negative but the slope is almost flat. Consistent with Bakshi, Cao and Chen (1997), our regression results show that implied volatility decreases with time to maturity.

For puts, both the presence and the magnitude of specialness are statistically significant and positive. Thus, we conclude that specialness increases the prices of puts. Calls prices do not show this sensitivity; neither the presence or the magnitude of specialness has a statistically significant effect on call prices. Thus, when we separate the synthetic short into its components we detect a significant positive effect of specialness on the cost of buying puts, and no effect on the revenue from writing calls.

\section{Abnormal Profits}

\section{C.1. Buy-in Costs.}

The other cost of failing, besides the foregone interest from the withheld purchase price, is the expected cost of being bought in. When the market maker is bought in, the clearing corporation executes the purchase, and the market maker must execute a new short sale to restore its position. Thus, the market maker's expected buy-in cost is the probability of a buy-in times this round-trip cost. Table II shows that 86 of the 69,063 failing positions, or $0.12 \%$, were bought in over the 2 -year period. Taking this realization as the expected incidence of buy-ins, the expected incidence of buy-in costs is this figure times the expected transactions cost, conditional on a buy-in.

Because the clearing corporation executes the buy-in, execution quality may not be optimized, and may therefore be costly to the market maker. To gauge this other leg of 
buy-in cost we relate the transaction prices of the 86 buy-ins to prevailing market prices. Table VI, Panel A shows that the buy-in trades are executed at prices $0.53 \%$ worse than the volume weighted average price (VWAP) for the given stock on the buy-in day. The departure from VWAP is statistically significant but even so, if we assume that the market maker pays the same $0.53 \%$ to put the short back on, the overall expected buy-in cost is $(0.12 \%)(2)(0.53 \%)$, or $0.1 \mathrm{bp}$. So the expected buy-in cost is, for our market maker at least, vanishingly small.

\section{C.2 Abnormal Profit Strategies}

In this section we combine the data on rebate rates and buy-in costs to calculate the profitability, to the market maker who provided our data, of providing synthetic shorts on hard-to-borrow stocks. In the section following we consider why the profits we document could be available in equilibrium.

Our profitability measure follows a simple trading strategy, designed to avoid the attribution issues documented by Battalio and Schultz (2005). In particular, we decide whether to put on the trade based on whether the stock is on special, not on whether our database shows disparity, and then we hold the trade to expiration. If instead we went in and out of the trade depending on the apparent disparity in the data, we would mistake some measurement error for profitability.

We focus on liquid options and reduce the influence of known biases by selecting the option pair with maturity as short as possible and moneyness closest to one. We also 
reduce the incidence of early exercise bias, without risking any look-ahead bias, by using only stocks that didn't pay dividends in the past year.

Our database allows us to calculate profits net of the exact shorting costs. If our market maker got a rebate we use that rebate but if they failed we use a rebate of zero. Assuming the market maker's opportunity cost of capital at time $t$ is the risk-free rate $r(t)$, and denoting his concurrent rebate for a given stock $q(t)$, the short sale cost paid by the borrower on day $t$ can be written $r(t)-q(t)$. If our data show that a stock was bought in, we subtract the cost of the buy-in by subtracting the buy-in price from the stock's VWAP that day. The assumption is that the market maker keeps the position going by shorting anew at VWAP on the same day. The profits from this strategy can be written as

$$
\underbrace{[\mathrm{S}(0)-\mathrm{S}(\mathrm{T})]}_{\text {Short Stock Position }}+\underbrace{\left[\mathrm{S}^{\mathrm{i}}(\mathrm{T})-\mathrm{S}^{\mathrm{i}}(0)\right.}_{\text {Synthetic Long Position }}]-\underbrace{\left[\sum_{\mathrm{t}=0}^{\mathrm{T}} \mathrm{S}(\mathrm{t})(\mathrm{r}(\mathrm{t})-\mathrm{q}(\mathrm{t}))\right]}_{\text {Reduced Rebate Costs }}-\underbrace{1_{\text {Buy In Indicator }}\left[\sum_{\mathrm{t}=0}^{\mathrm{T}}\left(\mathrm{S}_{\text {Buyin }}(\mathrm{t})-\mathrm{S}_{\text {VWAP }}(\mathrm{t})\right)^{\mathrm{r}(\mathrm{T}-\mathrm{t})}\right]}_{\text {Buy-In Round Trip Transaction Cost }}
$$

where the position is opened at $\mathrm{t}=0$ and closed at $\mathrm{t}=\mathrm{T}$.

We look at the profits to short-selling actual stock and buying synthetic stock whenever that stock goes on special. We see in Table VII that such a strategy would involve 6086 option pairs and yield an average profit of $\$ 0.1346$ per trade. The profit is statistically significant with a p-value of less than 0.001 , and corresponds to $\$ 13.46$ per option contract. Thus, the market maker profits, in equilibrium, by providing these synthetic shorts. In our final section we propose and test a hypothesis for why this happens.

D. Why Aren't Abnormal Profits Competed Away? 
What accounts for the equilibrium profitability we document? Why aren't more market makers buying these cheap synthetic long positions, bidding them up to zero profitability? We hypothesize that the clearing corporation handles fails in a way that favors higher-volume market makers, resulting in weaker competition when stocks grow special. We test this hypothesis on the relation between specialness and quoted spreads.

The hypothesis follows from how the clearing corporation assigns buy-ins. If a fail must be bought-in, this buy-in is assigned to the oldest fail (see Appendix A). Assuming a higher-volume market maker is more likely to move from a short position to flat (or positive) and back again, it is less likely to have the oldest fail and therefore less likely to be bought in. Thus, we hypothesize that higher-volume market makers, such as our data provider, enjoy a cost advantage with hard-to-borrow stocks, and that this advantage limits competition to make markets in the affected options.

If our market maker faces lower competition when specialness is higher then its market share of short exposure, i.e. its total short position as a fraction of economy-wide short interest, should grow as specialness grows. This would suggest that shorting via this option market maker, rather than some other way, becomes more attractive as shorting constraints tighten. Regressing the market share (Market Maker's SI)/(Market SI) on Specialness,, we find (p-values in parentheses):

$($ Market Maker's SI) / (Market SI $)=-0.06902+0.04037 *$ Specialness (0.2795) (0.0197)

Market share increases significantly with specialness, indicating that shorting frictions encourage shorting via this option market maker, and therefore that shorting frictions impose less cost on this option market maker than on traders in general. 
So this market maker gains short-interest market share as specialness grows, but in principle all option market makers could be gaining short-interest market share. To address the competitiveness between option market makers we need a measure of the current competition to make a market in a stock's options, and the natural candidate is the price charged, the current bid/ask spread.

Option spreads are subject to limits which often bind. ${ }^{5}$ The SEC, which sets these limits, finds that quoted spreads are at their maxima between $21 \%$ and $57 \%$ of the time (SEC, 2000). This is consistent with our sample; we find $36 \%$ of put options and $32 \%$ of call options at their maximum spreads. Thus, the relevant measure of spread width is whether it is at the maximum.

Accordingly, to relate spreads to specialness, we fit a probit model where the dependent variable indicates maximum width, and specialness is an explanatory variable. To control for demand-side circumstances that could affect spreads, we also include trading volume and open interest in the option, time to expiration and distance from atthe money (i.e. absolute value of $1-\mathrm{S} / \mathrm{K})$. The result is in Table VIII.

The probit strongly rejects the null; trading at the maximum spread increases significantly with specialness. Thus, the evidence supports the hypothesis that specialness weakens option-market competition.

\footnotetext{
${ }^{5}$ The Securities and Exchange Rule 1014(c)(i)(A) and Advice F-6 prescribe maximum quote spreads for equity options. The rule establishes maximum widths as follows: $\$ 0.25$ for options priced between $\$ 0.50$ and $\$ 2, \$ 0.375$ for options priced between $\$ 2$ and $\$ 5$, $\$ 0.5$ fro options priced between $\$ 5$ and $\$ 10, \$ 0.75$ for options priced between $\$ 10$ and $\$ 20$, and $\$ 1$ for options priced above $\$ 20$.
} 
Another way to test the hypothesis that turnover gives large market makers a cost advantage by protecting them from buy-ins is to test whether this advantage dissipates when volume drops. That is, we can test whether our data provider's success at avoiding buy-ins declines when option turnover declines. We do this by fitting a probit to all fails, where the dependent variable is whether (1) or not (0) the position is bought in, and the explanatory variables are option turnover (volume over open interest) along with other circumstances associated with buy-ins. What we find, in Table IX, is that turnover is significantly negative, as predicted: the less options turn over, the more the position is bought in.

Finally, we can see directly that our data supplier experiences an abnormally low incidence of buy-ins on its fails. On the average day, across the 502 sample trading days, this large market maker is failing on $4.4 \mathrm{M}$ shares. This is about $1.75 \%$ of the $\sim 250 \mathrm{M}$ fails on all NYSE/AMEX/NASDAQ stocks on the average day, in Boni (2005) (see Figure 1 of that paper). In Table II we see that our market maker experienced 86 buy-ins across the 502 days, or about $1 / 6$ buy-in per day. If this is about $1.75 \%$ of buy-ins, we should see about 10 buy-ins per day. But the DTCC reports more than 4,300 buy-in notices per day, ${ }^{6}$ and the fraction of notices that result in buy-ins is presumably greater than $1 / 430$. Thus, our data provider's fails appear relatively unlikely, compared to other traders' fails, to beget buy-ins.

\footnotetext{
${ }^{6}$ This figure represents only the notices transmitted via the DTC's Participant Exchange service; see "DTCC Will Automate and Streamline Buy-In Notification for Securities," a DTCC press release at http://www.dtcc.com/PressRoom/2005/buyin.html
} 


\section{Conclusion}

We show that the option to fail is significant to both the trading and pricing of equity options. We show that it is often in-the-money, and that when it is, market makers profit and so do their customers. The profit to market makers is puzzling, considering their competitiveness, but we resolve this puzzle by documenting limits to competition in options on hard-to-borrow stocks, and tracing these limits to the clearing corporation's rules for assigning buy-ins.

A delivery fail is nearly a single-stock futures contract, the only difference being the uncertainty about expiration. Thus, the popularity of failing may help explain why single-stock futures attract so little interest. The futures can improve on the spot when the spot is hard to borrow - this was the major selling point of the futures when they were introduced - but in that situation, fails provide the same improvement. Futures can provide other improvements, such as efficiencies with dividends and votes, but these are sparse in the fiscal year, unlikely to sustain trading.

The popularity of failing and the price improvements it provides short sellers encourage us to step back and consider the economic case for delivery. Delivery provides $100 \%$ insurance to both sides of a trade; by exchanging cash for securities, traders eliminate $100 \%$ of their mutual exposure. $100 \%$ insurance is unambiguously optimal when it is free, but not when it is costly, so the search for efficiency should bring traders to a mechanism for buying less insurance at a lower price when delivery is costly. This appears to be what they get by failing and margining through the clearing 
corporation. So while failing may sound mischievous or abusive, both our results here and basic economic reasoning indicate that its role is positive.

The SEC has taken a cautious approach by introducing its new Regulation SHO, which strengthens delivery requirements for "threshold securities," those with substantial current fails. Its effect on large market makers such as our data provider is likely small, since their hedging trades are still exempt from the locate requirement, and their fails do not age much (see Boni, 2005, for a complete description of the regulation), but it has the potential to alter the cost of short exposure, so its impact is an important new empirical question. Fortunately the lists of threshold securities are public, so proprietary data may not be necessary to answer it. 


\section{Appendix A. The Details of Short Selling and Delivery}

Short sellers sell stock they do not own. In the United States, exchange procedure generally requires short-sellers to deliver shares to buyers on the third day after the transaction $(t+3)^{7}$. Short sellers typically borrow stock and use the proceeds from the sale as collateral for the loan. Additionally, regulators and brokerages impose varying margin requirements on short positions. To close, or cover, the position, the short-seller buys shares and returns the shares to the lender.

\section{A. Borrowing and Rebate Rates}

Typically, a short-seller borrows shares from her broker. The proceeds from the short sale are used as collateral for the stock loan. The collateral earns interest, and the broker returns some of the interest to the short seller. The interest rate the short seller earns is known as the rebate rate. Rebate rates are generally lower for smaller investors, but for a given investor, lower rebate rates indicate more expensive loans. The majority of loans are cheap, but there are a few expensive loans in stock specials ${ }^{8}$.

Specials tend to be driven by episodic corporate events resulting in arbitrage opportunities for short-sellers. (See Geczy, Musto and Reed (2002) or D’Avolio (2002) for examples). Well placed investors, such as hedge funds, will be able to borrow stock specials and will earn the reduced rebate.

\footnotetext{
${ }^{7}$ See Bris, Goetzmann and Zhu (2004) for a description of short selling in other countries.

${ }^{8}$ Fitch IBCA's publicly available report: "Securities Lending and Managed Funds" estimates that the industry average spread from the fed funds rate to the general collateral rate on U.S. Equities is $21 \mathrm{bps}$.
} 


\section{B. Short-Selling When Borrowing is Difficult}

Exchange rules require most market participants to demonstrate that they can obtain hard to borrow shares before they short sel1 ${ }^{9}$. Market makers require an affirmative determination of borrowable or otherwise attainable shares. In market parlance, the short-seller needs a "locate" before short selling. However, there is an exception to the rule. An example is NASD's rule 3370(b), which exempts the following transactions from the affirmative determination requirement: “...bona fide market making transactions by a member in securities in which it is registered as a Nasdaq market maker, to bona fide market maker transactions in non-Nasdaq securities in which the market maker publishes a two-sided quotation in an independent quotation medium, or to transactions which result in fully hedged or arbitraged positions."

\section{Fails and Buy-Ins}

If the short sale is made on day $t$, the short seller's clearing firm generally delivers shares on day $t+3$. However, the National Securities Clearing Corporation (NSCC) procedures state: "each member has the ability to elect to deliver all or part of any short

\footnotetext{
${ }^{9}$ During our sample period, NYSE Rule 440C and NYSE Information Memorandum 91-41 require affirmative determination (a "locate") of borrowable or otherwise attainable shares for members who are not market makers, specialists or odd lot brokers in fulfilling their market-making responsibilities. Similarly, NASD Rule 3370 and NASD Rules of Fair Practice, Article III, Section 1, Interpretation 04 Paragraph (b)(2)(a) (See Ketchum, 1995, and SEC Release No. 34-35207), and Securities Exchange Act Release No. 27542 (AMEX) require affirmative determination of borrowable shares during the period treated in the paper (SEC Release No. 34-37773).
} 
position." $" 10$ If a clearing firm decides to deliver less than the full amount of shares to its buyers, the firm is failing to deliver shares.

If the clearing firm fails, the best-case scenario for the short seller is for the buyer's broker to allow the fail to continue as long as the short position is open. In this case, the short seller's cost of short exposure is the lost interest on the transaction amount. When borrowing shares, the short-seller would also lose the full interest income on his collateral in the case of a zero rebate rate. Economically, a failed delivery is the same as delivery of borrowed stock at a zero rebate rate as long as the buyer's broker allows the fail to continue.

In the worst-case scenario, the buyer's broker insists on delivery by filing a notice of intention to buy in with the NSCC at $t+4$ in accordance with NSCC's Rule $10^{11}$. The notice is retransmitted from the NSCC to the seller's broker on $t+5$, and the seller has until the end of day $t+6$ to resolve the buy-in liability. If the seller does not resolve the liability, a "buy-in" occurs: the buyer purchases shares on the seller's account to force delivery $^{12}$. If her position is bought in, the seller may then short sell again to re-establish the short position. In this case, the short seller will pay the execution costs of the buy-in and the following short sale every six days ${ }^{13}$. Figure A1 shows the sequence of events in each scenario.

\footnotetext{
${ }^{10}$ NSCC Procedures, VII.D.2.

${ }^{11}$ The Securities and Exchange Commission's Customer Protection Rule requires clearing firms to possess shares in fully paid accounts. Clearing firms may attempt to acquire shares to be in compliance with the SEC's rule.

${ }^{12}$ The seller's clearing firm buys shares in a buy-in for NYSE and AMEX stocks, the buyer's clearing firm buys-in shares of NASDQ stocks.

${ }^{13}$ NASD Rule 11810 (c)(1)(B) gives buyers the option to buy guaranteed delivery shares, and there have been complaints regarding the purchase price of guaranteed shares. A limited supply of guaranteed delivery
} 
The NSCC allocates buy-ins across clearing firms and clearing firms allocate buyins across clients. Failing clients can protect themselves against buy-ins at both levels. Figure A2 shows the institutional structure. In the first stage, the NSCC ranks clearing firms according to the date of failed deliveries, and the NSCC allocates buy-ins to the clearing firms with the oldest failed delivery first ${ }^{14}$. As a result, clearing firms that frequently change from short to long net positions are less likely to be bought in. Once the NSCC allocates buy-ins to a clearing firm, that clearing firm must allocate buy-ins among its clients. Clearing firms have discretion over this second-stage of the selection decision, and, unlike the first stage, there are no market-wide rules. Anecdotal evidence suggests that clearing firms use their discretion; they allocate a disproportionately small number of buy-ins to protected clients.

shares, combined with the transparency of the underlying purpose for the purchase may inflate prices. Second, according to NASD Regulation's general counsel Alden Adkins in Weiss (1998), "there are no hard and fast rules dictating the prices at which buy-ins can take place. But [Adkins] says the prices must be 'fair' - and that the person who sets the price must be prepared to defend it."

${ }^{14}$ This description provided here is a slight simplification of the actual procedure. For a more specific example of what really happens, assume that $\mathrm{N}+0$ represents the date the Buy-In Notice is filed. Filing such a notice will give the firm higher priority in settlement on the first business day after filing, $\mathrm{N}+1$ and on the second business day after filing, $\mathrm{N}+2$, if the long position remains unfilled. On date $\mathrm{N}+1$, if the position remains unfilled, NSCC submits "retransmittal notices" to the firm(s) with the oldest short position in the Buy-In stock. These notices specify the Buy-In liability for the short firm and the name of the long firm instigating the Buy-In. "If several firms have short Positions with the same age, all such Members are issued Retransmittal Notices, even if the total of their Short Positions exceeds the Buy-In position." ${ }^{14}$ Once they receive the retransmittal notice, other settling trades may move them to a flat or even a long position in the stock but do not exempt them from their Buy-In liability. The short firm has until the end of day $\mathrm{N}+2$ to resolve their Buy-In liability. Before the retransmittal notice is received, a buy-in liability is removed once a net long position of sufficient size is established. 


\section{Appendix B. Risk-Free Interest Rates}

We construct a database of daily risk-free interest rates using Federal Reserve 1, 7, 15, 30, 60 and 90-day AA financial commercial paper discount rates which we convert to bond equivalent yields. ${ }^{15}$ The risk-free rate corresponding to option maturity is calculated by linearly interpolating between the two closest interest rates. For example, the risk-free rate for an option with maturity of 6 days would be calculated by linearly interpolating between the 1-day and the 7-day discount rates.

The method of linear interpolation is an approximation to the true term structure, and the error inherent in the approximation is greatest for near-term maturities. By using the rates on commercial paper, the error in minimized relative to rates on T-bills or other fixed income instruments that are only reported for greater maturities. As a check on our procedure, we also calculate the risk-free rate with daily GOVPX data on T-bills using a procedure similar to Bakshi, Cao and Chen (1997). The correlation coefficient between the 3-month AA financial commercial paper rate and the 3-month T-bill rate reported by the Federal Reserve is 0.98. As a further check, we regress our 3-month commercial paper rate on the Federal Reserve's 3-month T-bill rate from September 1997 to August 2001. The intercept is not significantly different from zero, the slope is statistically significant (the coefficient is 0.90 ), and the $\mathrm{R}^{2}$ is

\footnotetext{
${ }^{15}$ Bond Equivalent Yield $=($ Discount/100)(365/360)/(1-(Discount/100) $($ Time to Maturity/360) $)$ This is equivalent to the yield formula reported in the Wall Street Journal and is commonly used in option markets and for debt instruments with maturities of less than one year.
} 
Figure A1. Clearing, Failing and Buying-In

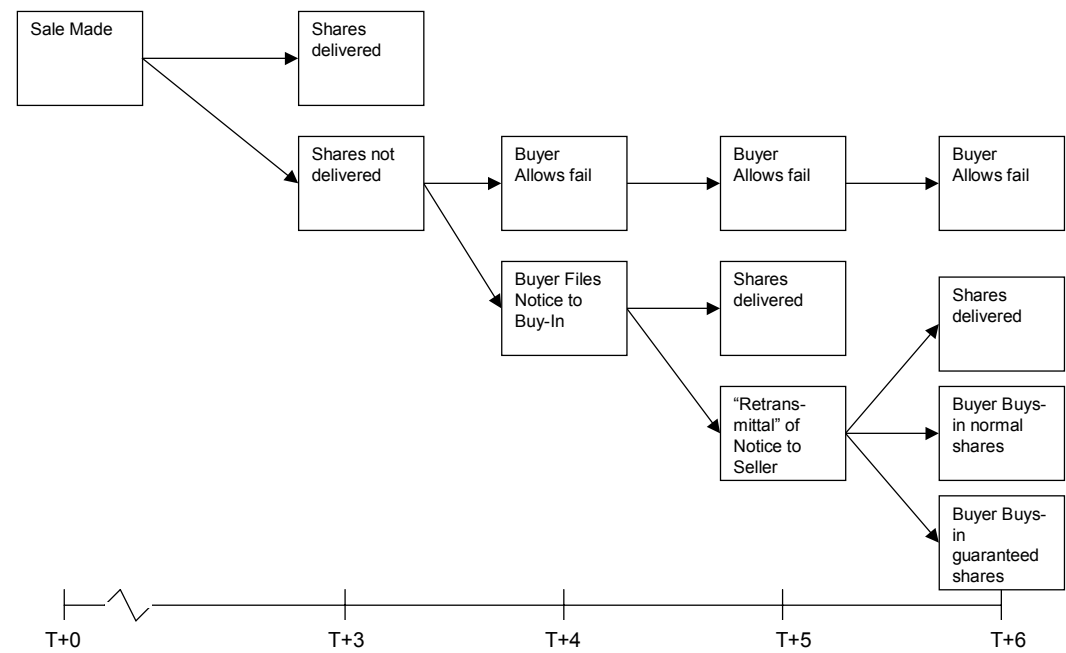

Figure A2. The Structure of Clearing Institutions

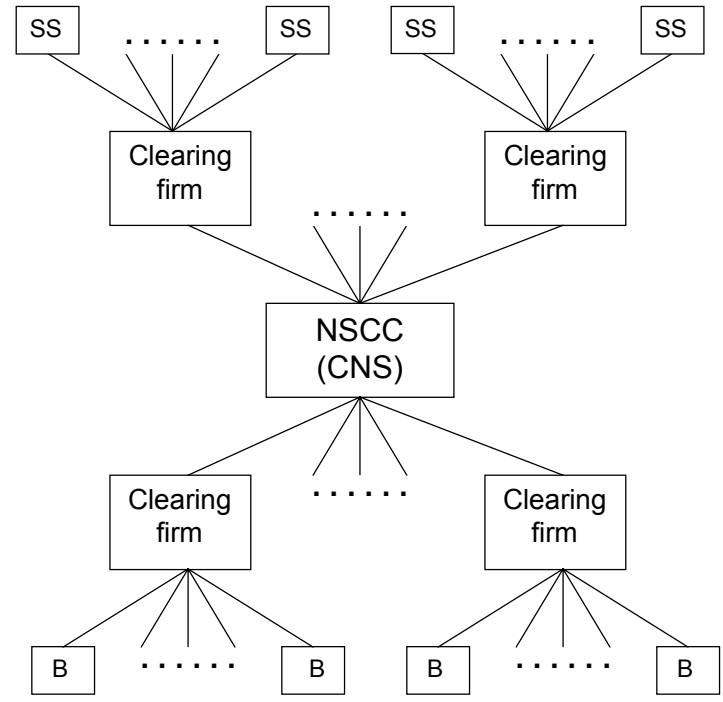




\section{GLOSSARY}

Buy-In - A situation where shares are purchased in the stock market to insure delivery for a buyer to whom shares are owed.

Clearing - The delivery of shares from buyer to seller. A clearing firm provides clearing and settlement services for exchange members.

Continuous Net Settlement (CNS) System - An automated book-entry accounting system that centralizes the settlement of security transactions for the NSCC.

Delivery Versus Payment (DVP) System - A system allowing delivery and payment to be exchanged instantaneously. DVP is used by market participants for settlements that are not automatically handled by CNS.

Failure to Deliver - A situation where the seller does not the give the buyer shares on the settlement date.

General Collateral Rate - The prevailing interest rate earned on borrowers' collateral for equity loans.

Guaranteed Delivery - A stock transaction where the seller commits to a settlement date and allows the buyer to cancel trade if delivery is not made. Delivery terms are negotiated on a trade-by-trade basis; trades often have non-standard clearing (e.g. $t+1$ )

Locate - An affirmative determination that the short-seller will be able to borrow shares to deliver to the buyer. Affirmative determination may include assurances from a shortseller that the customer can borrow shares in time for settlement or that the security is found on "easy to borrow" lists. In some situations, market participants must provide a locate to the stock market maker before short-selling.

Notice of Intention to Buy-In - An indication to the NSCC that the buyer will force delivery of shares. After the notice is filed, the buyer's priority for delivery is increased. The notice of intention to buy-in can be filed four days after trading if securities are not delivered.

National Securities Clearing Corporation (NSCC) - Securities clearing organization providing centralized clearing and settlement for the NYSE, AMEX and NASDAQ.

Hard To Borrow - A situation where stock loans are difficult or expensive. Institutionally, certain restrictions apply unless a stock is not hard to borrow.

Rebate Rate - The interest rate earned by borrowers on collateral for equity loans. Rebate rates are reduced below prevailing rates when stocks are on special. 
Retransmittal Notice - The NSCC's indication to the seller that the buyer plans to buy-in shares. A notice of the buyer's notice to buy-in from the NSCC to the seller. A retransmittal notice is sent one day after a notice of intention to buy-in has been sent if the buyer has not received shares.

Settlement - The exchange of shares for payment.

Settlement Date -- The date on which payment is made to settle a trade. For stocks traded on US exchanges, standard settlement is three days after the trade $(\mathrm{t}+3)$.

Short Sale - A transaction where the seller sells shares she does not own.

Specialness - The difference between the general collateral rebate rate and stock-specific rebate rate. Specialness is typically zero. A stock is said to be on special if specialness is positive.

Street Name - Brokerage or nominee registration as opposed to the direct account holder registration. Securities held in street name can be lent to short sellers with the permission of the owner. 


\section{REFERENCES}

Asquith, Paul, 1983, Merger bids, uncertainty, and shareholder returns, Journal of Financial Economics 11, 51-83.

Bakshi, Gurdip, Charles Cao, and Zhiwu Chen, 1997, Empirical performance of alternative option pricing models, Journal of Finance 52, 2003-2049.

Bakshi, G., N. Kapadia, D. Madan, 2003, Stock return characteristics, skew laws, and the differential pricing of individual equity options", Review of Financial Studies 16, 101143.

Battalio, Robert H., and Paul H. Schultz, 2005, Options and the bubble, Journal of Finance, forthcoming.

Black, Fisher and Myron Scholes, 1973, The pricing of options and corporate liabilities, Journal of Political Economy 81, 637-654.

Boni, Leslie, 2005, Strategic Delivery Failures in U.S. Equity Markets, working paper, University of New Mexico.

Bradley, Daniel, Bradford Jordan, Ivan Roten and Ha-Chin Yi, 2003, Venture capital and IPO lockup expiration: An empirical analysis, Journal of Financial Research 24, 465492.

Brav, Alon, and Paul A. Gompers, 2003, The role of lockups in initial public offerings, Review of Financial Studies 16, 1-29.

Brent, Averil, Dale Morse, and E. Kay Stice, 1990, Short interest: Explanations and tests, Journal of Financial and Quantitative Analysis 25, 273-289.

Bris, Arturo, William N. Goetzmann and Ning Zhu, 2004, Efficiency and the Bear: Short Sales and Markets around the World, Working Paper, Yale University

Christoffersen, Susan C., Christopher G. Geczy, David K. Musto and Adam V. Reed, 2005a, Cross-Border Taxation and the Preferences of Taxable and Non-Taxable Investors: Evidence from Canada. Journal of Financial Economics 78, 121-144.

Christoffersen, Susan C., Christopher G. Geczy, David K. Musto and Adam V. Reed, 2005b, Vote Trading and Information Aggregation. Working Paper, McGill, Wharton and UNC.

Cox, John C., Stephen A. Ross, and Mark Rubinstein, 1979. Options pricing: a simplified approach, Journal of Financial Economics, 7, 229-263. 
D'Avolio, Gene, 2002, The market for borrowing stock, Journal of Financial Economics 66, 271-306.

Das, Sanjiv Ranjan and Rangarajan K. Sundaram, 1999, Of smiles and smirks: A term structure perspective, Journal of Financial and Quantitative Analysis 34, 211-239.

Dennis, P., S. Mayhew, 2002, "Risk-Neutral skewness: Evidence from stock options", Journal of Financial and Quantitative Analysis 37, 471-493.

Derman, Emanuel and Iraj Kani, 1994, "Riding on a Smile”, Risk 7, 32-39.

Diamond, Douglas W., and Robert E. Verrecchia, 1987, Constraints on short-selling and asset price adjustment to private information, Journal of Financial Economics 18, 277311.

Duffie, Darrell, Nicolae Gârleanu, and Lasse Heje Pedersen, 2002, Securities lending, shorting, and pricing, Journal of Financial Economics 66, 307-339.

Dumas, Bernard, Jeff Fleming, and Robert E. Whaley, 1998, Implied volatility functions: Empirical tests, Journal of Finance 53, 2059-2106.

Fama, Eugene and James MacBeth, 1973, Risk, return and equilibrium: Empirical tests, Journal of Political Economy 81, 607-636.

Field, Laura C., and Gordon Hanka, 2001, The expiration of IPO share lockups, Journal of Finance 56, 471-500.

Figlewski, Stephen, 1989, Options arbitrage in imperfect markets, Journal of Finance 44, 1289-1311.

Figlewski, Stephen and Gwendolyn P. Webb, 1993, Options, short sales, and market completeness, Journal of Finance 48, 761-777.

Fleming, Michael J. and Kenneth D Garbade, 2002, When the Back Office Moved to the Front Burner: Settlement Fails in the Treasury Market after 9/11, Federal Reserve Bank of New York Economic Policy Review 8, 35-57.

Geczy, Christopher C., David K. Musto, and Adam V. Reed, 2002, Stocks are special too: An analysis of the equity lending market, Journal of Financial Economics 66, 241269.

Hentschel, Ludger, 2003, Errors in implied volatility estimation. Journal of Financial and Quantitative Analysis 38, 779-810.

Hull, John C., Options, Futures and Other Derivatives, Upper Saddle River, NJ: Prentice Hall Inc., 2000. 
Information Memo Number 91-41, October 18, 1991, "Rule 440C Deliveries Against Short Sales," New York Stock Exchange.

Jarrow, Robert and Maureen O’Hara, 1989, Primes and Scores: An Essay on Market Imperfections, Journal of Finance 44, 1263-1287.

Jennings, Robert, and Laura Starks, 1986, Earnings announcements, stock price adjustment, and the existence of option markets, Journal of Finance 41, 107-125.

Jensen, Michael C., and Richard S. Ruback, 1983, The market for corporate control, Journal of Financial Economics 11, 5-50.

Johnson, Omotunde E. G., 1998, The Payment System and Monetary Policy, International Monetary Fund Papers on Policy Analysis and Assessment.

Jones, Charles M., and Owen A. Lamont, 2002, Short sale constraints and stock returns, Journal of Financial Economics 66, 207-239.

Kahn, Charles M., and William Roberds, 2001, The CLS Bank: A Solution to the Risks of International Payments Settlement?, Carnegie-Rochester Conference Series on Public Policy 54, 191-226.

Keasler, Terrill R., 2001, Underwriter lock-up releases, initial public offerings and aftermarket performance, Financial Review 37, 1-20.

Ketchum, Richard G., Official Correspondence from CEO and EVP, NASD to Richard Lewandowski, Director, The Options Exchange, July 26, 1995.

Klemkosky, R. C. and Resnick, B.G., 1979, Put call parity and market efficiency. Journal of Finance 42, 1141-1155.

Lamont, Owen A. and Richard H. Thaler, 2003, Can the market add and subtract? Mispricing in tech stock carve-outs. Journal of Political Economy 111, 227-268.

Longstaff, Francis A., 1995, Option pricing and the Martingale restriction, Review of Financial Studies 8, 1091-1124.

Macbeth, James D. and Larry J. Merville, 1979, An empirical examination of the Black-Scholes call option pricing model, Journal of Finance 34, 1173-1186.

Manaster, Steven and Richard J. Rendleman, Jr., 1982, Option prices as predictors of equilibrium stock prices, Journal of Finance 37, 1043-1057.

Mitchell, Mark, Todd Pulvino and Erik Stafford, 2002, Limited arbitrage in equity markets, Journal of Finance 57, 551-584. 
Ofek, Eli, and Matthew Richardson, 2000, The IPO lock-up period: implications for market efficiency and downward sloping demand curves, Working Paper, New York University.

Ofek, Eli and Matthew Richardson, 2003, DotCom Mania: The Rise and Fall of Internet Stock Prices, Journal of Finance, 58, 1113-1138.

Ofek, Eli, Matthew Richardson and Robert Whitelaw, 2004, Limited arbitrage and short sales restrictions: Evidence from the options markets, Journal of Financial Economics, $74,305-342$.

Peña, Ignacio, Gonzalo Rubio, and Gregorio Serna, 1999, Why do we smile? On the determinants of the implied volatility function, Journal of Banking \& Finance 23, 11511179 .

Reed, Adam, 2001, Costly short-selling and stock price adjustments to earnings announcements, Working Paper, The University of North Carolina.

Rubinstein, Mark, 1985, Nonparametric tests of alternative option pricing models using all reported trades and quotes on the 30 most active CBOE options classes from August 23, 1976 through August 31, 1978, Journal of Finance 40, 455-480.

Securities and Exchange Commission, 1996, "Release No. 34-37773; File No. SR-Amex96-05," Federal Register, V 61, No. 197.

Securities and Exchange Commission, 1995, "Release No. 34-35207; File No. SRNASD-95-01,” Federal Register, V 60, No. 10.

Securities and Exchange Commission Office of Compliance Inspections and Examinations, 2000, "Special Study: Payment for Order Flow and Internalization in the Options Markets", http://www.sec.gov/news/studies/ordpay.htm

Skinner, Douglas J., 1990, Options markets and the information content of accounting earnings releases, Journal of Accounting and Economics 13, 191-211.

Strong, Norman and Xinzhong Xu, 1999, Do S\&P 500 index options violate the Martingale restriction?, The Journal of Futures Markets 19, 499-521.

Weiss, Gary, 1998, Were the Short Sellers Ripped Off?, Business Week, 3572, 118-119 


\section{Table I}

\section{Option Database Filters}

This table presents the number of observations excluded by each filter applied to the options database. As in Bakshi, Cao and Chen (1997), we delete observations where call prices are higher than the underlying stock prices $(C>S)$. We delete observations where call prices are less than the present value of payoffs if exercised $(\mathrm{C}<\mathrm{S}-\mathrm{PV}(\mathrm{K})-$ PV(Div)). We delete observations where put prices are less than the current value of exercise $(\mathrm{P}<\mathrm{K}-\mathrm{S})$. We delete observations where put prices are above their strike prices $(\mathrm{P}>\mathrm{K})$. We also delete options with less than 6 calendar days to maturity or greater than 180 calendar days to maturity and options with a price less than $\$ 0.375$.

\begin{tabular}{|l|r|r|r|r|r|r|}
\hline \multicolumn{1}{|c|}{ Filters } & \multicolumn{2}{|c|}{ Filters in Isolation } & \multicolumn{4}{c|}{ Filters in Sequence } \\
\hline & $\begin{array}{c}\text { Obs. } \\
\text { Excluded }\end{array}$ & $\begin{array}{c}\text { \% Original } \\
\text { Excluded }\end{array}$ & $\begin{array}{c}\text { Obs. } \\
\text { Exlcluded }\end{array}$ & $\begin{array}{c}\text { \% Original } \\
\text { Excluded }\end{array}$ & $\begin{array}{c}\text { Obs. } \\
\text { Remaining }\end{array}$ & $\begin{array}{c}\% \text { Original } \\
\text { Remaining }\end{array}$ \\
\hline & & & & & $19,723,466$ & $100 \%$ \\
\hline $\mathrm{C}, \mathrm{P}<.375$ & $3,564,681$ & $18.07 \%$ & $3,564,681$ & $18.07 \%$ & $16,158,785$ & $81.93 \%$ \\
\hline $\mathrm{tau}>180$ & $3,866,290$ & $19.60 \%$ & $3,744,692$ & $18.99 \%$ & $12,414,093$ & $62.94 \%$ \\
\hline $\mathrm{tau}<6$ & $1,074,310$ & $5.45 \%$ & 533,918 & $2.71 \%$ & $11,880,175$ & $60.23 \%$ \\
\hline $\mathrm{C}>\mathrm{S}$ & 0 & $0.00 \%$ & 0 & $0.00 \%$ & $11,880,175$ & $60.23 \%$ \\
\hline $\mathrm{C}<\mathrm{S}-\mathrm{PV}(\mathrm{K})$ & 578,906 & $2.94 \%$ & 442,774 & $2.24 \%$ & $11,437,401$ & $57.99 \%$ \\
\hline $\mathrm{P}<\mathrm{K}-\mathrm{S}$ & 0 & $0.00 \%$ & 0 & $0.00 \%$ & $11,437,401$ & $57.99 \%$ \\
\hline $\mathrm{P}>\mathrm{K}$ & 0 & $0.00 \%$ & 0 & $0.00 \%$ & $11,437,401$ & $57.99 \%$ \\
\hline
\end{tabular}




\section{Table II}

\section{Rebate Rates, Failure and Buy-In Frequency}

This table presents statistics on the 1998-99 rebate rate, fail and buy-in database from a large options market maker. Panel A. shows the overall incidence of five equity loan states in the database: General Collateral (GC), Reduced Rebate (RR), Reduced Rebate/Fail (RRF), Fail Only (F) and Buy-in (BUY) and the average rebate rate associated with each state. Panel B. shows the percentage of daily stock positions in each one of three categories: (i) No Failing, where there are no shares failing delivery, (ii) Partial Failing, where there is at least one share failing delivery, and (iii) Failing, where every share is failing delivery. Percentages are based on the total number of observations, $1,512,000$.

Panel A. Incidence of Loan States in the Database

\begin{tabular}{|c|c|c|c|c|c|}
\hline $\begin{array}{c}\text { Loan } \\
\text { State }\end{array}$ & Frequency & Percent & $\begin{array}{c}\text { Cumulative } \\
\text { Frequency }\end{array}$ & $\begin{array}{c}\text { Cumulative } \\
\text { Percent }\end{array}$ & $\begin{array}{c}\text { Average } \\
\text { Rebate Rate }\end{array}$ \\
\hline GC & $1,379,594$ & 91.24 & $1,379,594$ & 91.24 & 4.98 \\
\hline RR & 63,343 & 4.19 & $1,442,937$ & 95.43 & 1.72 \\
\hline RRF & 59,322 & 3.92 & $1,502,259$ & 99.36 & 1.50 \\
\hline F & 9,655 & 0.64 & $1,511,914$ & 99.99 & 0.34 \\
\hline BUY & 86 & 0.01 & $1,512,000$ & 100 & 0.00 \\
\hline
\end{tabular}

Panel B. Rebate Rates for Failing and Non-Failing Positions

\begin{tabular}{|l|c|c|c|c|}
\hline & Rebate $>0$ & Rebate $=0$ & Rebate $<0$ & Total \\
\hline No Failing & $98.61 \%$ & $1.39 \%$ & $0.00 \%$ & $95.43 \%$ \\
\hline Partial Failing & $59.36 \%$ & $40.64 \%$ & $0.00 \%$ & $3.92 \%$ \\
\hline Failing & $10.35 \%$ & $89.65 \%$ & $0.00 \%$ & $0.64 \%$ \\
\hline Total & $96.50 \%$ & $3.50 \%$ & $0.00 \%$ & $100 \%$ \\
\hline
\end{tabular}


Table III

The Distribution of Put-Call Disparity and Specialness

This table describes the distribution of put-call disparity, specialness and rebate rates in the sample of 4,560,217 strike price and maturity matched put-call pairs. Put-Call Disparity is the difference between the stock price and the options implied stock price normalized by the stock price, i.e. $\left(S-S^{i}\right) / S$. Specialness is the difference between the general rebate rate and the specific rebate rate for a stock. Rebate Rate is the interest rate on cash collateral in a stock loan.

\begin{tabular}{|l|c|c|c|}
\hline & $\begin{array}{c}\text { Put-Call } \\
\text { Disparity }\end{array}$ & $\begin{array}{c}\text { Specialness } \\
(\mathbf{\%})\end{array}$ & $\begin{array}{c}\text { Rebate Rate } \\
(\mathbf{\%})\end{array}$ \\
\hline Average & 0.0036 & 0.48 & 4.47 \\
\hline Median & 0.0028 & 0 & 4.85 \\
\hline Standard Deviation & 0.0179 & 1.30 & 1.34 \\
\hline Minimum & -0.9988 & -0.07 & 0 \\
\hline Maximum & 0.5617 & 5.80 & 5.80 \\
\hline $5^{\text {th }}$ Percentile & -0.0098 & 0 & 0 \\
\hline $10^{\text {th }}$ Percentile & -0.0053 & 0 & 3.00 \\
\hline $90^{\text {th }}$ Percentile & 0.0140 & 1.92 & 5.33 \\
\hline $95^{\text {th }}$ Percentile & 0.0195 & 4.50 & 5.40 \\
\hline
\end{tabular}




\section{Table IV}

\section{Implied Stock Prices and Short Sales Constraints}

This table presents estimates from a panel regression of the following form:

$$
\Delta_{j, t}=\mathrm{a}+\text { bSpecialness }_{\mathrm{j}, \mathrm{t}}+\mathrm{c} \text { Moneyness } \mathrm{j, \textrm {t }}+\mathrm{d} \text { Time-to-Maturity } \text { Sit, }_{\mathrm{t}}+I D(j)+I D(t)+e_{j, t} \text {. }
$$

$\Delta_{j, t}$ is the put call disparity of stock $j$ on day $t$. Specialness $s_{\mathrm{j}, \mathrm{t}}$ is the difference between the general rebate rate on day $t$ and the specific rebate rate for a stock $j$ on day $t$.

Moneyness $\mathrm{j}_{\mathrm{j}, \mathrm{t}}$ is the price of stock $j$ on day $t$ divided by the strike price of the option pair.

Time-to-Maturity is the number of calendar days to expiration of the option. The ID functions represent a fixed effects treatment of both the cross sectional (by stock) and time series (by day) effects. The regression uses one put and one call on each stock every day; of the options with the shortest time to maturity, those with moneyness closest to one are chosen. Only option pairs are used where the volume and open interest of both the put and the call are non-zero. Panel B uses borrowing rates from a custodian bank to examine the impact of specialness on put-call disparity in both borrowing and failing regimes when stocks are on special. An indicator that takes the value of one when rebate rates are negative, and zero otherwise, is interacted with specialness to create a second specialness variable: specialness when rebates are negative, or Negative Specialness. In Panel B, the sample is limited to stocks with positive specialness. For each regression the p-value of the Hausman cross-sectional fixed effects specification test is reported.

Panel A. Market Maker's Specialness

\begin{tabular}{|l|cccc|}
\hline Variable & Estimate & Std.Dev. & t-Stat & p-Value \\
\hline Intercept & -0.0071 & 0.00166 & -4.27 & $<.0001$ \\
Specialness & 0.060017 & 0.00302 & 19.86 & $<.0001$ \\
Moneyness & 0.006047 & 0.000782 & 7.74 & $<.0001$ \\
Time-to-Maturity & 0.000017 & $3.292 \mathrm{E}-6$ & 5.06 & $<.0001$ \\
\hline R-Square & 0.1548 & & & \\
Number of Observations & 84915 & & & \\
Hausman Test p-Value & $<.0001$ & & & \\
\cline { 1 - 3 } & & & &
\end{tabular}

Panel B: Custodial Specialness and Negative Specialness

\begin{tabular}{|l|ccrc|}
\hline Variable & Estimate & Std.Dev. & t-Stat & p-Value \\
\hline Intercept & -0.00278 & 0.002980 & -0.93 & 0.3511 \\
Specialness & 0.088 & 0.000156 & 5.64 & $<.0001$ \\
Negative Rebate Specialness & -0.048 & 0.000171 & -2.83 & 0.0046 \\
Moneyness & 0.00242 & 0.002150 & 1.12 & 0.2613 \\
Time-to-Maturity & 0.00004 & 0.000008 & 5.00 & $<.0001$ \\
\hline R-Square & 0.2706 & & & \\
Number of Observations & 29387 & & & \\
Hausman Test p-Value & $<.0001$ & & & \\
\hline
\end{tabular}


Table V

Implied Volatilities and Short-Sale Constraints

This table presents estimation results from a panel regression of the following form: $\sigma_{j, t}^{\text {implied }}-\sigma_{j, t}^{\text {average implied }}=\gamma_{0}+\gamma_{1}$ Moneyness $_{j, t}+\gamma_{2}$ Time-to-Maturity $_{j, t}+\gamma_{3}$ Specialness $_{j, t}+I D(j)+I D(t)+e_{j, t}$. $\sigma_{j, t}^{\text {implied }}$ is the implied volatility of a put or a call option for stock $j$ on day $t$, and $\sigma_{j, t}^{\text {average }}$ implied is the average implied volatility of the put and the call for stock $j$ from day $t$ through expiration. Implied volatilities are calculated using the Cox, Ross and Rubinstein binomial tree method. One put and one call is selected on each stock every day; of the options with the shortest time to maturity, those with moneyness closest to one are chosen. This difference is then regressed on Moneyness, Time-to-Maturity and two specifications of Specialness: the actual value of specialness and an indicator that takes the value of one if the stock has specialness greater than $100 \mathrm{bp}$, and zero otherwise. The ID functions represent a fixed effects treatment of both cross-sectional (by stock) and daily (by day) effects. The Hausman fixed effects specification test p-value is reported. ***Indicates Statistical Significance at the $0.1 \%$ Level. **Indicates Statistical Significance at the 1\% Level. *Indicates Statistical Significance at the 5\% Level.

\begin{tabular}{|c|c|c|c|c|c|c|c|c|c|c|c|c|}
\hline & \multicolumn{6}{|c|}{ Calls } & \multicolumn{6}{|c|}{ Puts } \\
\hline Intercept & 1.05271 & $* * *$ & 1.053132 & $* * *$ & 1.052391 & $* * *$ & 0.927512 & $* * *$ & 0.917619 & $* * *$ & 0.911268 & * \\
\hline Moneyness & -0.03807 & ** & -0.03803 & $* *$ & -0.03808 & ** & 0.092928 & $* * *$ & 0.092066 & *** & 0.092254 & $* * *$ \\
\hline Time-to-Maturity & -0.00066 & $* * *$ & -0.00066 & *** & -0.00066 & *** & -0.00084 & ${ }^{* * *}$ & -0.00084 & *** & -0.00084 & $* * *$ \\
\hline Specialness & & & -0.02581 & & & & & & 0.605971 & *** & & \\
\hline $100 \mathrm{bp}$ Indicator & & & & & 0.00033 & & & & & & 0.01678 & *** \\
\hline Observations & 84915 & & 84915 & & 84915 & & 84915 & & 84915 & & 84915 & \\
\hline $\mathrm{R}^{2}$ & 0.6640 & & 0.6640 & & 0.6640 & & 0.6776 & & 0.6782 & & 0.6779 & \\
\hline Hausman & $<0.001$ & & $<0.001$ & & $<0.001$ & & $<0.001$ & & $<0.001$ & & $<0.001$ & \\
\hline
\end{tabular}




\section{Table VI \\ Buy-In Execution}

This table presents statistics on the execution of buy ins in 1998 and 1999 for a major market making firm. After merging the database with TAQ, there are 85 buy-in observations on 24 unique stocks. The execution quality of the buy-ins is examined by comparing the buy-in prices to the volume-weighted average price (VWAP) over the trading day, $\left(S_{B U Y I N}-S_{V W A P}\right) / S_{V W A P}$. In Panel A, we report the mean, median and standard deviation of the execution costs. Additionally, we report a t-test of the null hypothesis that the difference is zero. If multiple buy-in events are recorded on a single day, the buy-in price used in the calculations is the quantity-weighted execution price. In Panel B, we report the quantity of shares bought-in and the number of trading days from buy-in to settlement.

\begin{tabular}{|c|c|} 
Panel A: Execution Costs \\
\hline Mean & 0.0053 \\
Median & 0.0028 \\
Std.Dev. & 0.0178 \\
t-stat & 2.75 \\
p-Value & 0.01 \\
\hline
\end{tabular}

Panel B: Buy-In Quantity and Timing

\begin{tabular}{|l|c|c|}
\hline & $\begin{array}{c}\text { Buy-In } \\
\text { Quantity }\end{array}$ & $\begin{array}{c}\text { Trading Days to } \\
\text { Settlement }\end{array}$ \\
\hline Mean & 9,512 & 3.01 \\
Median & 3,915 & 3 \\
Std.Dev. & 14,450 & 0.24 \\
\hline
\end{tabular}




\section{Table VII \\ Put-Call Arbitrage Profits}

This table lists arbitrage profits from short selling stock and buying a strike and time to maturity matched combination of options to replicate the underlying stock. The short stock, long synthetic stock arbitrage trade is put on whenever the stock is on special, and closed at option expiration. Borrowing costs are included in the profit calculation. If the database indicates a buy-in occurs while the position is open, the short position is closed at the indicated buy-in price. The short-sale is then re-established that day using the volume-weighted average price. There are no positions where the underlying stock paid a dividend in the previous year. Trade duration is the number of days a particular position is open. Signed trade profit indicates the percentage of individual positions with positive and negative profits. The strategy uses one option-pair per stock (the pair that is closest to the money and nearest term in maturity).

\begin{tabular}{|c|ccccc|}
\hline & $\mathrm{N}$ & Mean & Std. Dev. & t-Stat & p-Value \\
\hline Arbitrage Profit & 6086 & 0.1346 & 0.4579 & 22.93 & $<0.001$ \\
\hline & Median & Mean & & & \\
\hline Trade Duration (in days) & 35 & 47.66 & & & \\
\hline & Positive & Negative & & \\
\hline Signed Trade Profit & $67.58 \%$ & $32.42 \%$ & & \\
\hline
\end{tabular}




\section{Table VIII \\ Incidence of Maximum Spreads}

This table presents estimation results from a probit regression of the incidence of maximum option quote spreads on specialness and other control variables. To construct the dependent variable, call and put options are matched by underlying stock, time to maturity and strike price. The dependent variable is one if both the put and the call have quoted spreads at their maximums, and zero otherwise. AbsVal(1-Moneyness) is the absolute value of $[1-$ (stock price)/(strike price) $]$. Volume is the sum of the daily volume for the put and the call. Open interest is the sum of open interest for the put and the call. Time-to-maturity is the number of days to the expiration of the option. Fixed cross-sectional effects (by stock) are included in the regression.

\begin{tabular}{|c|cccc|}
\hline Parameter & Estimate & P-Value & Average & Marg. Effect \\
\hline Intercept & -2.5377 & $<0.0001$ & & \\
Specialness & 1.1680 & $<0.0001$ & 0.00572 & 0.4637 \\
AbsVal(1-Moneyness) & 0.1881 & $<0.0001$ & 0.12462 & 0.0747 \\
Volume & -0.0001 & $<0.0001$ & 267.366 & -0.00004 \\
Open Interest & -0.0001 & $<0.0001$ & 2237.01 & -0.00002 \\
Time to Maturity & 0.0003 & $<0.0001$ & 60.2556 & 0.0001 \\
\hline
\end{tabular}




\section{Table IX \\ Determinants of Buy-Ins}

This table presents estimation results from a probit regression of buy-ins on specialness, short interest and other potentially predictive variables. The regression is specified so the probability of being bought-in is estimated. Option turnover is the average ratio of the daily volume divided by the current open interest for the put/call pair that is trading closest to the money and nearest term in maturity on the underlying stock. Specialness is the cost of short-selling. Short interest is the monthly total short position in a stock reported by the exchanges. Shares outstanding is the CRSP reported number of total shares outstanding on the stock. Standard deviation is calculated from daily returns over the previous six months. Price Indicator takes the value of 1 for stocks with a closing midquotes less than or equal to $\$ 5$, and zero otherwise. The sample comprises 64 buy-in events and 33201 non-buy-in events. The reported marginal effect is calculated as the average marginal effect for a 1 unit change in all observations in the sample. *Because the option turnover variable is used to test the hypothesis of refreshing the age of the market maker's failure to deliver and thereby lowering the position of the market maker on the list of buyin allocations, they hypothesis predicts a negative coefficient. Consequently, the p-value for option turnover is from a 1-sided test.

\begin{tabular}{|l|ccc|}
\hline \multicolumn{1}{|c|}{ Parameter } & Estimate & P-Value & Marg. Effect \\
\hline Intercept & -3.367 & $<0.001$ & \\
Option Turnover & -0.287 & $0.035^{*}$ & -0.0016 \\
Specialness (\%) & 0.330 & $<0.001$ & 0.0018 \\
Log(Short Interest) & 0.082 & 0.061 & 0.0005 \\
Log(Shares Outstanding) & -0.353 & $<0.001$ & -0.0020 \\
Daily Std. Dev. (6 Months) (\%) & -0.041 & 0.086 & -0.0002 \\
Price Indicator (<\$5) & 4.240 & $<0.001$ & 0.0234 \\
\hline
\end{tabular}

